\section{Kloning af store pattedyr - teknik, konsekvens, etik og rettigheder}

\author{
af seniorforsker, lic.scient. Anne PhaffUssing- \\ Rosenkilde
}

Undertegnede var inviteret som én af foredragsholderne ved Hestekongressen 2006, som afholdtes i Fredericia slutningen af januar. Det store diskussionsemne i år var kloning af heste.

\section{En klonet hest i Danmark}

I løbet af efteråret 2005 har medierne oplyst, at den klonede hest Paris Texas er i live, har det godt og bor i Danmark. Det er altså nu teknisk muligt at klone heste. Det har naturligvis affødt en række spørgsmål; dels om, hvorvidt det overhovedet er etisk forsvarligt at klone pattedyr, dels om, hvorvidt afkommet skal kunne registreres, og i givet fald hvordan afstamningsforholdene skal anføres.

Et faderløst får og en moderløs hest Først hørte vi om făret Dolly, og nu hesten Paris Texas. Begge dyr er fremstillet ved voksenkloning, men herefter hører lighederne også op. Den største forskel, man umiddelbart kan få øje på, er at Dolly har en mor, men ingen far. Paris Texas har en far, men ingen mor. Kigger man nærmere på de to kloningsteknikker, som er blevet benyttet, er der endnu flere forskelle.

\section{Voksenkloning}

Fåret Dolly blev skabt af DNA fra celler udtaget af moderens - eller måske skulle man snarere sige tvillingesøsterens - mælkekirtler (brystvæv). Cellerne blev dyrket i laboratoriet, hvor de først blev stimuleret til at dele sig; derefter blev delingerne standset. DNA fra udvalgte celler blev høstet og indsat i ægceller, som var blevet tømt for deres eget kerne-DNA. Derefter blev embryonet (det tidlige foster) indsat i en rugemor. Dolly har samme kerne-DNA som sin mor, men cellematerialet i ægcellen, herunder det cytoplasmatiske DNA, stammer fra ægdonoren (et slagtefår). Det omgivende miljø, nemlig den livmoder, den rugemor, og selve de fysiske omgivelser, var også forskellige fra dem, som Dollys moder voksede op i.

Hesten Paris Texas blev skabt af DNA fra én af faderens - eller tvillingebroderens - hudceller. DNA'et blev overført til en ægcelle fra en donorhoppe. Ægcellen var forinden blevet tømt for sit eget kerneDNA. Denne celle, med kernemateriale fra en hingst, og cytoplasmatisk DNA samt øvrige cellebestanddele fra en ægdonor, blev derefter indsat i en rugemor. I kloningen af Paris Texas indgår tre forskellige heste, nemlig faderen (donoren af hudcellen), donoren af ægcellen (en slagtehoppe), og rugemoderen, som alle tre har indflydelse på fosterets udvikling. Men: Der er kun én af dem, som har betydning for de føl, som Paris Texas kan blive far til, nemlig Quidam de Revel, som har leveret kerne-DNA'et.

\section{Hvordan fandt man på at klone en hest?}

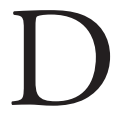
et er givet mange, som har overvejet - eller haft lyst til - at forsøge at klone en hest. Måske er der endda en del, som har forsøgt, uden at det er lykkedes. Det får verden aldrig at vide, medmindre det er sket $i$ et land, hvor der er givet tilladelse til forsøget. Der er udført godkendte og vellykkede forsøg på kloning af dyr fra Equus-slægten fire gange i perioden 2003- 
2005. Forsøgene er udført i Italien og USA, i samarbejde med et laboratorium i Frankrig.

Den første klonede "hest" var et muldyr! Det første klonede dyr af slægten Equus var et muldyr - en hybrid, som fremkommer ved krydsning af æselhingst og hestehoppe. Muldyr er oftest sterile, fordi hest og æesel ikke har samme kromosomtal. Derfor er der en mere oplagt grund til at klone muldyr; de kan kun yderst sjældent reproducere sig selv. Det samme gælder den "omvendte" krydsning, mulæsel, hvor hestehingst krydses med æselhoppe.

Muldyret Idaho Gem er en klon af en bror til væddeløbsmuldyret Taz. Man valgte at skabe et nyt foster ved at krydse Taz's forældre med hinanden endnu engang. Da fosteret var i vækst, blev det udtaget, og kerne-DNA høstet og indsat i en ægcelle fra en hestehoppe. Ægcellen blev derefter indsat i en rugemoder, ligeledes en hestehoppe. Idaho er således ikke tvillingebror til Taz, men almindelig bror. Kloningen var lidt snyd, fordi man fremstillede et foster i den hensigt at høste DNA fra det; men det var det første, banebrydende forsøg på at klone Equus, så det har banet vejen for de senere udførte voksenkloninger. Idaho Gem blev født i Idaho i 2003. I processen medvirkede fem dyr: æselhingsten, hestehoppen, fosteret, ægdonoren og rugemoderen. Det forlyder, at der er flere klonede muldyr på vej,

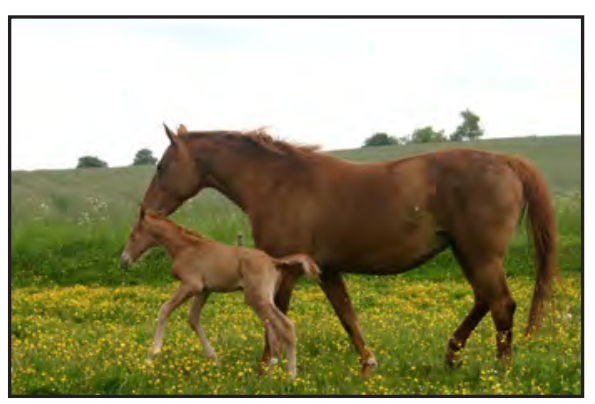

med kerne-DNA fra det samme foster som Idaho Gem.

Den første "rigtige" hesteklon

Den første klonede hest er en haflinger, født i Italien i 2003. Hoppeføllet Prometea er fremstillet af DNA fra huden af sin mor - eller tvillingesøster. DNA'et blev indsat i en tømt celle fra en donorhoppe, og derefter indsat i den hoppe, som donerede DNA'et. Prometea har altså sin egen genetiske tvillingesøster som rugemor. Der medvirkede således kun to heste i processen, fordi DNA-donor og rugemor var den samme. Herudover medvirkede donoren af ægcellen. I hele forsøget indgik dog mange ægdonorer, og flere rugemødre; men det var kun den ægcelle, som var indsat i DNA-donoren, som resulterede i et levedygtigt føl. Føllets navn er en logisk afledning af Prometeus.

Kloning af en vallak

Verdens anden klonede hest er PierazCryozootech-Stallion, som blev født i Italien i 2005. Faderen - eller tvillingebroderen er arabervallakken Pieraz, som vandt VM i distance i 1994 og 1996. Ejeren er den amerikanske distancerytter Valerie Kanavy. Pieraz-Cryozootech-Stallion er frembragt af det samme forskerteam, som frembragte Prometea, og metoden er den samme, bortset fra at der her indgår en hoppe mere, altså i alt tre heste, idet Pieraz af gode grunde ikke

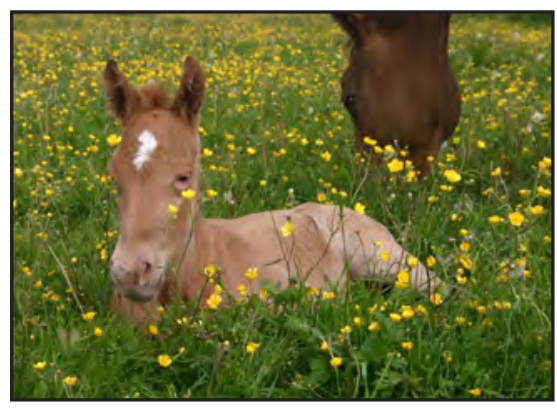


selv kunne fungere som rugemor.

\section{Den danske klon}

$\mathrm{I}$ Danmark var det hingsteejeren Flemming Velin, som valgte at få sin tophingst, Quidam de Revel, klonet. Velin har selv afholdt udgifter hertil, og har overholdt alle de regler, som var og er gældende i de lande, hvor det foregik. Hesten er fuldt lovligt importeret til Danmark.

\section{Quidam de Revel er en spring-} hest af international klasse, og den har virket som avlshingst i mange år. Hingsten er franskfødt, af racen Selle Francais. Rugemoderen er en hoppe af racen American Quarter Horse ved navn Greta. Kloningen er sket i samarbejde med A\&M University of Texas, College Station, hvor man både råder over metoderne, har et internationalt forskerteam, ledet af professor Katrin Hinrichs, og hvor man arbejder efter høje moralske idealer. Også her medvirkede det franske laboratorium Cryozootech, som har specialiseret sig i nedfrysningsteknikker.

Hvor éns er far og søn så?

Paris Texas har præcis det samme kerne-DNA som sin berømte far, Quidam de Revel; dvs. de to hingste er identiske med hensyn til, hvilke egenskaber de kan give videre til deres afkom. En hingst giver - som alle handyr inden for pattedyrene - udelukkende kerneDNA til afkommet, mens en hoppe - som

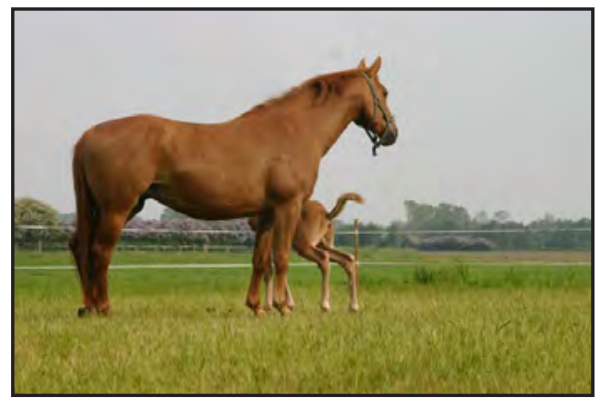

alle hundyr inden for pattedyrene - giver både kerne-DNA og cytoplasmatisk DNA til afkommet. At Paris Texas har ligget i en anden ægcelle end Quidam, og at den hele livet vil have sin donormoders DNA i cytoplasmaet i alle sine celler, i stedet for sin genetiske moders (som er identisk med Quidams moder), har betydning for nogle af dens egne egenskaber, men betyder intet for afkommet, idet de ikke gives videre fra hingsten. Den sæd, som dannes i de to hingste, er arvemæssigt identisk.

Betydningen af den cytoplasmatiske arv er langt fra klarlagt. Det, man kender bedst, er mitokondrierne (cellernes "energifabrikker"). Mitokondrier nedarves udelukkende fra moderen, idet de befinder sig i cytoplasmaet. Desuden er der forhold som styrer, hvorledes generne făr indflydelse på afkommets udvikling. Nogle gener kommer kun til udtrykket hos afkommet, hvis de er nedarvet fra moderen. Det er (endnu) ikke vist, om det f.eks. skyldes, at der findes egenskaber i cytoplasmaet, som skal være til stede for at disse gener aktiveres, eller kan fungere.

Jamen de ligner ikke hinanden...

Reaktioner på billeder af føllet har været tydelige. De fleste hæfter sig ved, at føllet har anderledes hvide aftegn end sin far (nærmere bestemt flere "hvide sokker"). Men dette har intet med arven fra faderen at

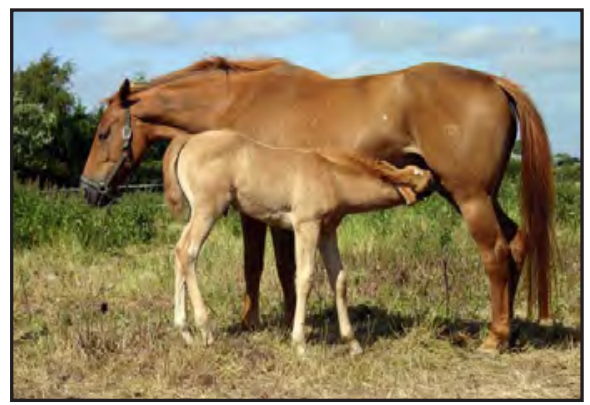




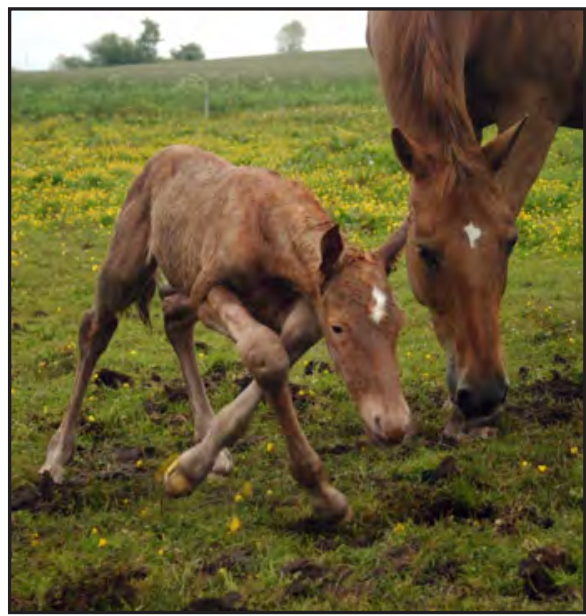

gøre. Hvide aftegn på hoved og ben - genetisk betegnet som recessivt hvidt - skyldes arveanlæg som har stor fænotypisk variation. Man kan ikke aflæse, om kloningen er "lykkedes" eller "slået fejl" ved at sammenligne føllets hvide sokker med faderens. Den samme hest har jo heller ikke identiske aftegn på alle fire ben, og en blis er ikke nødvendigvis symmetrisk, hvilket må være tydeligt for enhver, som har set bare et lille udvalg af heste.

Kommer det klonede føl til at springe lige så godt som faderen?

Nej, det er der ingen, som forventer. Men man afventer naturligvis med spænding, hvilke egenskaber føllet viser, efterhånden som det vokser til. Det har Quidams kerneDNA, ægdonorens cytoplasmatiske DNA og andre celleegenskaber, og har fået næring fra rugemoderen i fostertilværelsen.

Dertil kommer, at føllet var født lille, efter hele 12 måneders drægtighed i en hoppe, som er mindre end man forventer at føllet bliver. Det har været hævdet, at føllet var svagt og måtte i kuvøse, men dette er en misforståelse. I deres iver for at føllet skulle få en god start, på trods af den lange drægtighed i en måske for lille livmoder, stod fødselshjælperne parat med et iltaggregat, som blev spændt om føllets mule. Heldigvis blev det ikke nødvendigt at give den nyfødte ilt, og kort efter fødslen stod den og diede. Føllet tog hurtigt på, og var allerede få måneder efter fødslen ikke længere lille af sin alder. Føllet blev straks døbt Daniel (Paris Texas er "arbejdsnavnet" for kloningsprojektet).

\section{The X-factor}
A vlere af væddeløbsheste har i flere hundrede år vidst, at bestemte egen- skaber havde det med at springe en generation over. Det gælder helt præcist det store hjerte og de store lunger, som er altafgørende for, at en hest kan løbe hurtigt og holde farten over længere distancer (altså mere end nogle få hundrede meter, eftersom der er tale om baneløb). Fænomenet har fået navnet "The X-factor", nu hvor det er klart, at det er egenskaber, som nedarves via Xkromosomet. Sønner af hingste arver X-kromosomet fra moderen, og Y-kromosomet fra faderen. Døtre, derimod, arver et X-kromosom fra hver af forældrene; men det er moderens X-kromosom, der bestemmer hjertets størrelse hos hoppeføllene. Først når de selv er voksne og bliver mødre, kommer det Xkromosom, de arvede fra faderen, til udtryk - og vel at mærke kun i den halvdel af føllene, som arver morfaderens X-kromosom. Før man kendte noget til kromosomer, blev fænomenet derfor kaldt "morfader-effekten". X-faktoren blev først opdaget hos den legendariske væddeløbshest Eclipse, som var ubesejret i 1700 -tallet. Dens afkom udmærkede sig ikke særligt på væddeløbsbanerne, men det gjorde en del af dens døtres afkom, en generation senere. Eclipse er aktuel i 2006, fordi forskere er i gang med at analysere dens skelet (se www.bbc.com). 


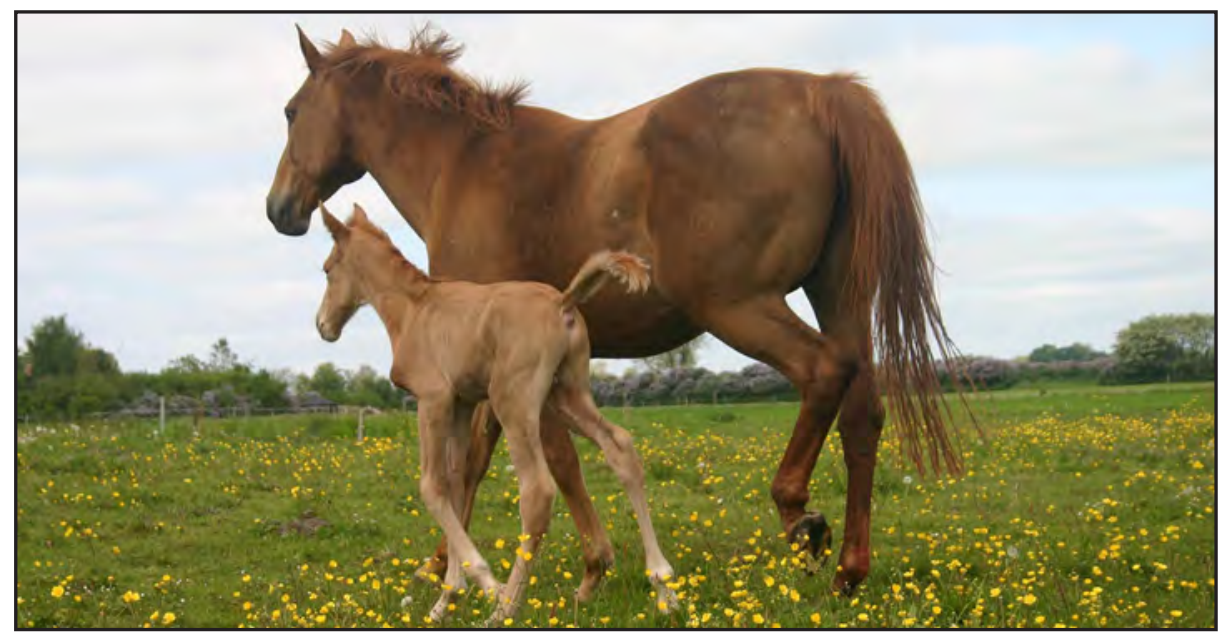

I tilfældet Daniel betyder det, at selv hvis Quidam har "The X-factor", vil egenskaben ikke nødvendigvis udvikles hos Daniel, selvom den jo nødvendigvis har det sammeX-kromosom som Quidam. For Daniel har jo ligget i et andet æg, end Quidam gjorde i sin tid.

Hvordan kan man vide, at den kan få "samme føl" som faderen?

Det kan man, fordi det nukleære DNA er identisk. Ikke bare nogenlunde éns, men præcis éns. Derfor vil det arvemateriale, Daniel giver videre til sine forhåbentlig kommende afkom, være identisk med det DNA, som Quidam giver videre til sine afkom.

Bliver alle dens føl så éns?

Nej, det gør de ikke. De er jo ikke kloner, men er dannet på den almindelige måde, hvor arveanlæggene fra forfædrene blandes og deles, lige som et spil kort.

Dels vil de allerfleste af føllene være halvsøskende, idet de har forskellige mødre. Dels giver hingsten kun halvdelen af sit arvemateriale videre til hvert af sine føl.
Der sker en reduktionsdeling, og forud for denne sker der overkrydsning af kromosomerne, hvorved generne blandes og derefter skilles ad igen. (Dette kan man læse om i basale biologibøger, hvis man ikke lige har det present). Selv helsøskende blandt heste er ikke mere éns end helsøskende hos mennesket.

Helsøskende arver halvdelen af faderens nukleære DNA - men ikke præcis den samme halvdel - og halvdelen af moderens nukleære DNA - heller ikke her præcis den samme halvdel. Disse to halvdele smelter sammen og giver tilsammen arvemassen i afkommet. Hvilke gener, som kommer til udtryk i afkommet, afhænger af forskellige forhold. Nogle egenskaber er enten dominante eller vigende - her bestemmer de dominante. Andre egenskaber nedarves co-dominant - her bestemmer moderens og faderens arveanlæg lige meget. Nogle egenskaber reguleres ved dosis-kompensation. Det gælder den vilkårlige inaktivering af X-kromosomet hos hunner. Det gælder også fysiologiske egenskaber, som ellers er co-dominante. Hvis det ene af disse gener er defekt, vil det andet blive sat til at replicere i dob- 
belt dosis, så organismen kan fungere alligevel. Desuden er der epigenetisk regulering, herunder "genomic imprinting": at det er forudbestemt, hvilket af de to arveanlæg, som stammer fra henholdsvis faderen og moderen, der skal bestemme. Endelig er der den cytoplasmatiske arv, som kun videregives fra moderen.

Der er således store forskelle i arvelige forhold, selv hos helsøskende. Hos halvsøskende vil der være endnu større forskelle, idet arveanlæggene fra den ene af forældrene er forskellige. Altså: der er absolut ingen grund til at tro, at Daniel vil få mere énsartet afkom end alle mulige andre hingste får det, blot fordi den er klonet.

\section{Etiske betragninger}

$\mathrm{D}$ er har været mange - og meget forskellige - synspunkter fremme i forhold til, om det er etisk forsvarligt over for dyrene at klone dem. De anfægtelser, der primært har været anført, er:

\section{"Man afskaffer sex"}

På dette kan svares, at sex i forbindelse med avl af dyre konkurrenceheste allerede er afskaffet i det omfang, der benyttes kunstig befrugtning. Nogle hingsteejere lader stadig deres dyr bedække ved naturmetoden. Andre mener, at det er for risikabelt. Der er risiko for smitte, bl.a. med virusabort. Der er risiko for, at enten hoppen eller hingsten lider overlast: hingsten kan bide hoppen, hoppen kan sparke hingsten. Det er ikke forsvarligt at transportere et føl, som er mindre end én måned gammelt, sammen med moderen, når den skal til hingst. (Hopper går drægtige 11 måneder; hvis de også skal have føl året efter, skal de derfor bedækkes kort tid efter folingen). Atter andre hingsteejere har hestene ude i konkurrencer det meste af året; derfor kan de ikke stå til avlstjeneste hjemme i hele bedækningssæsonen, men "springer" på fantom og leverer sæd i de perioder, hvor det passer i stævnekalenderen.

\section{"Man standser det biologiske ur"}

Det biologiske ur er allerede standset i det omfang, man benytter frost- eller kølesæd. Især frostsæd kan bevares i mange år og give afkom, længe efter at hingsten er $\mathrm{d} ø \mathrm{~d}$, blevet ufrugtbar, eller på anden måde ophørt med at fungere $i$ avlen.

"Man fratager dyrene deres biologiske integritet"

Denne indvending gælder primært de involverede ægdonorer og rugemødre. Især de sidste indgår i en proces, hvor de gøres drægtige og enten får afbrudt drægtigheden for at fosterets udvikling kan studeres, eller skal føde et andet moderdyrs afkom.

Ægdonorerne er for en stor del slagteheste, dvs. de skal alligevel lade livet for at blive til (menneske)føde. De etiske overvejelser over, hvorledes æggene benyttes, kan vel derfor betragtes som meget små i det samlede billede.

For så vidt angår rugemødrene kan det hævdes at de, i det omfang de får lov at føre drægtigheden til ende og opfostre føllet, må formodes at have samme glæde som hvis det var deres eget føl. I de tilfælde, hvor drægtigheden blev afbrudt, er det ikke oplyst, om moderdyret samtidig blev slagtet, eller der blev udført kejsersnit. Den afbrudte drægtighed er i mange tilfælde et krav i forbindelse med forsøg, som involverer kloning af dyr. Dette må derfor betragtes som en nødvendig del af den forskning, som skal til, før man tager stilling til, om kloning er acceptabel, og kan gennemføres fuldt ud, i de enkelte lande.

I den kommercielle mælkeproduktion har det længe været en kendsger- 


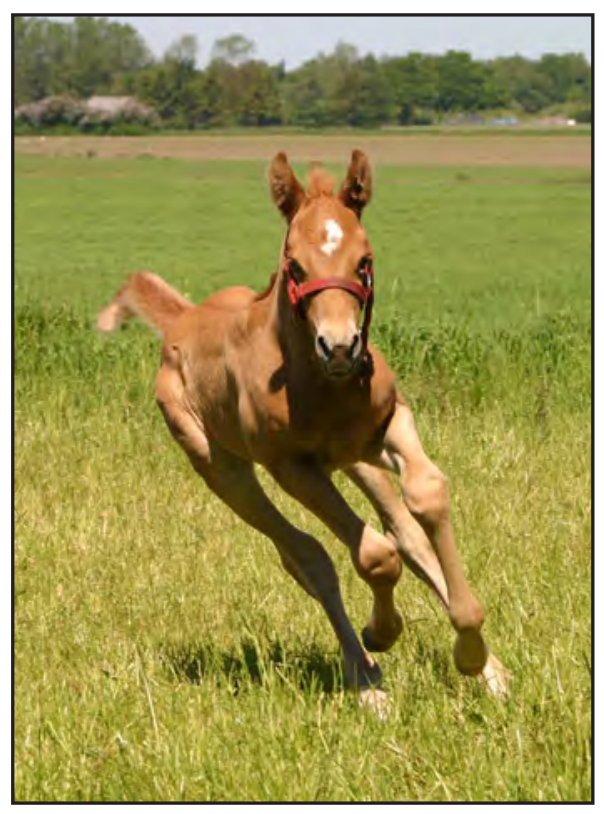

ning, at køerne måtte producere en kalv om året for at opretholde en acceptabel mælkeydelse. En del - primært tyrekalve - slagtes umiddelbart. De kalve, som fodres op, tages fra moderen efter kælvningen og opfostres på erstatningsfoder, fordi mennesket skal bruge den mælk, der biologisk set er bestemt for kalvene. Hvis man vil forsvare dyrs biologiske integritet, ved at sikre at pattedyrmødre får lov at opfostre deres egne unger, kunne man forestille sig, at der var større grund til at bekymre sig for malkekøerne. Ikke mindst fordi der er mange flere malkekøer, der har den skæbne, end der er hopper, som indgår i produktion af klonede føl. Desuden er der absolut ingen biologisk baggrund for at tro, at køer er mindre intelligente, eller har færre moderskabsfølelser, end hopper har.

"Skal man så også klone kæledyr?" At nogle mennesker har en forestilling om, at de kan erstatte en kær afdød kat, hund eller kælekanin ved at få klonet en celle fra dens skind, er et andet perspektiv. Kan man overhovedet regne med, at den bliver magen til? Nej, det kan man ikke, for der er mange elementer, som spiller ind i forbindelse med individets udvikling. Ingen ved endnu med sikkerhed, hvor mange faktorer der indgår i udvikling af personlig adfærd og følelsesliv. Desuden vil klonede dyr, afhængig af kloningsmetoden, have større og mindre forskelligheder, også selvom de har det samme DNA i cellekernerne. Mit personlige råd ville være (hvis vi går ud fra, at det er en hund): Tag til samme kennel, udvælg en hvalp af samme race, men forsøg at fà en anden farve, og helst også det modsatte køn. På den måde er der sandsynlighed for, at den nye hund ligner den gamle lidt, og hermed opfylder ejerens mest basale behov i forbindelse med valg af kæledyr. Det, at den ikke ligner den anden for meget, vil hjælpe ejeren til ikke at identificere hunden med den tidligere, men i stedet give den mulighed for at udvikle sin egen adfærd, personlighed og integritet.

"Vil alle topheste blive klonet fremover?" På ingen måde. Det er både dyrt og besværligt at klone en hest, og det er stadig under én procent af de klonede embryoner, som ender med et levendefødt føl. Der indgik mange befrugtede æg, ægdonorer og et antal rugehopper, da Daniel og de andre Equus-kloner blev fremstillet.

Selvom det må antages, at det efterhånden bliver noget nemmere og mere omkostningsvenligt at klone heste, betyder det dog langt fra, at det er noget som en hvilken som helst hesteavler har råd til - eller har lyst til. Kloning vil stadig være undtagelsen, mens det må formodes, at de allerfleste hesteavlere vil foretrække at avle på en måde, som er tættere på den naturlige. 
Hvordan stambogsføres klonede heste?

I Danmark registreres de fleste heste hos

Landscentret | Heste, som hører under

Dansk Landbrugsrådgivning. Heste, som er efter anerkendte, avlsgodkendte forældre, registreres med stamtavle. Heste, som ikke opfylder disse krav, registreres uden afstamningsoplysninger - også selvom afstamningen er kendt.

Det har været diskuteret, hvorledes en klonet hests stamtavle kunne og skulle se ud. Det er en kendsgerning, at hvis klonede heste, og deres afkom, ikke kan registreres med afstamning, vil de blive registreret som efter ukendte forældre. Heste uden anerkendt afstamning vil ikke kunne avlsgodkendes i Danmark. Hvor stort er dette problem så?

Hvis der var tale om dressurheste, kunne problemet være stort, for de fleste dressurryttere går meget op i hestenes afstamning. Springryttere derimod, er gennemgående mest interesserede $\mathrm{i}$, om hesten kan springe.

I militarysporten kan man se, at en stor del af hestene er registreret med "ukendt afstamning". Det betyder ikke nødvendigvis, at man ikke ved, hvem hestenes forældre er, men derimod at deres afstamning ikke er anerkendt i noget avlsforbund. Militaryheste er ofte $7 / 8$ fuldblod, dvs. en ekstra forædling af irsk hunter. Den irske hunter avles traditionelt med fuldblodshingste og koldblodshopper af racen Irish Draught. Førstegangs-krydsningen kaldes sværvægtshunter - det betyder, at den kan bære en stor og kraftig rytter på en hel dags jagt. Andengangs-krydsningen, igen med fuldblod, kaldes letvægtshunter, og svarer mere til en moderne ridetype. Krydser man videre med fuldblod, kan hestene ikke registreres som huntere - og heller ikke i noget andet avlsforbund. Men man får en fremra-

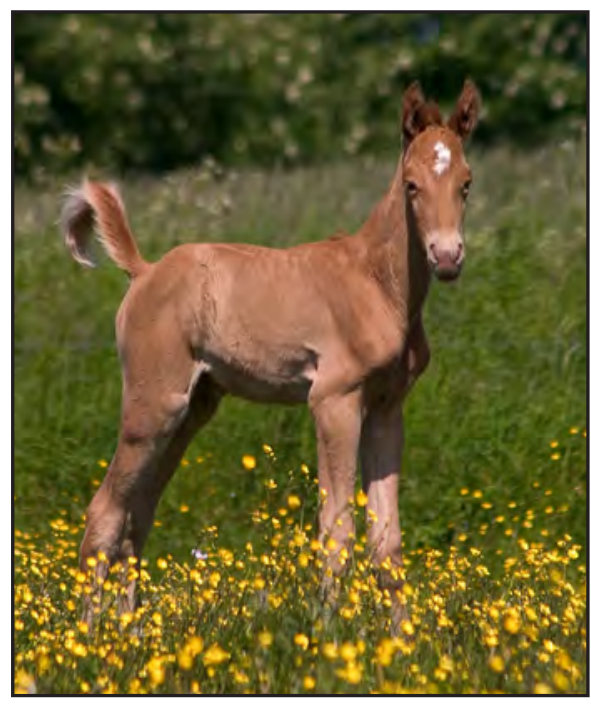

gende militaryhest, med fuldblodets hurtighed og mod, kombineret med lidt mere substans i knoglerne, og måske lidt mere roligt gemyt, fra koldblodshesten.

Det samme, altså registrering uden afstamningsoplysninger, kunne blive resultatet for spring- og distanceheste efter en klonet hingst, hvis de ikke kan registreres efter gældende regler.

I Europa har det belgiske avlsforbund Zangersheide vedtaget at anerkende heste, som er klonet på Cryozootechlaboratoriet. Kravet er, at der udføres DNAtest, som bekræfter, at føllets DNA-profil er identisk med ophavets. Både PierazCryozootech-Stallion og Daniel er således blevet registreret med Euro Passport, udstedt af Studbook Zangersheide, Belgien.

Det primære formål med kloningen af disse to er, at de skal kunne give generne videre, altså virke i avlen. Hermed kan selv en vallak som Pieraz få videregivet sine gener. Selvom World Arabian Horse Organization (WAHO) har nægtet at anerkende Pieraz-Cryozootech-Stallion, vil der helt sikkert være bud efter den, og dens føl 
vil kunne registreres i Studbook Zangersheide, sådan som den selv er blevet det, med navnet Pieraz Z (CL) OX. Daniels officielle navn, som fremgår af hestepasset, er Quidam de Revel Z (CL) 1.

Kloner i konkurrencer og væddeløb Idaho Gem får måske en fremtid på væddeløbsbanen, for klonede muldyr er tilladt i muldyrvæddeløb i USA.

Væddeløbsheste af engelsk fuldblod må ikke reproduceres på anden måde end den naturlige, så vi kommer ikke til at se klonede fuldblodsheste på væddeløbsbanerne. Det kan dog ikke udelukkes, at de vil kunne starte som "NITSB" (Not In The Stud Book).

Der er ingen afstamningskrav til spring- eller distanceheste, så selv hvis PierazCryozootech-Stallion og Daniel ikke var blevet registreret med afstamningsoplysninger, havde de kunnet deltage i konkurrencer.

Zangersheide er medlem af World Breeding Federation for Sport Horses (WBFSH), så hestenes anerkendelse på internationalt plan skulle hermed være fastslået. FEI har dog nedsat en arbejdsgruppe, som vil diskutere klonede hestes deltagelse i konkurrencer.

\section{Kloning i fremtiden}

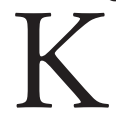

loning er kommet for at blive - også af heste, og i Danmark. Danmark er i forvejen et af de førende lande inden for bioteknologi, så min personlige mening er, at vi skal være med på fronten og være meningsdannende inden for området kloning af pattedyr. Alt, hvad der kan lade sig gøre for penge, og som kan give penge, vil blive udført et eller andet sted i verden. Så hellere i Danmark, hvor man tør gå ud fra, at hestevelfærd er en selvfølge.

Personligt mener jeg, at Flem- ming Velin har bidraget med noget meget værdifuldt, både til forskningen og til hestesportsverdenen, hvor Daniel forhåbentlig vil komme til at stå til rådighed som avlshingst.

Vallakker kan blive fædre

Kloning gør det muligt for en vallak at blive far. Ikke personligt, men in absentia, idet man kan klone en vallak, så dens klon (eller tvillingebror) kan blive far til de føl, den ikke selv kunne få, fordi den var kastreret. Der er forsøg i gang med kloning af to topspringheste: den østrigske springrytter Hugo Simons vallak E.T., samt Willi Melligers springhest Calvaro Z, som døde i 2003, $171 / 2$ år gammel. Hensigten er, at de kommende hingste skal bruges i avlen - hvis ellers kloningerne lykkes og resulterer i levedygtige føl. Sæden kan allerede bestilles hos Cryozootech i Frankrig, eller Keros NV i Belgien.

Befolkningens holdning og viden

De argumenter, jeg har hørt, selv fra personer, som man kunne formode havde sat sig ind i arvelighed, har gjort mig opmærksom på, at biologiundervisningen i Danmark langt fra er tilstrækkelig. Vi bevæger os mod et teknologisk samfund, og alle vil have holdninger, og være med til at bestemme, hvad forskerne må eller ikke må. De fleste danskere har meninger om gensplejsning og kloning. Men de allerfærreste har sat sig ind i den helt basale, lettilgængelige viden om arvelighed. F.eks. Mendels krydsningsforsøg med ærteblomster, som viser at begge forældre har indflydelse på afkommet. Eller de rent mekaniske forhold ved celledeling, såsom mitosen og meiosen. Eller den cytoplasmatiske arv.

Det er desværre en udbredt misforståelse i hesteverdenen, at faderen 
har størst indflydelse på afkommet - selv om det i virkeligheden er omvendt, når det gælder pattedyr. Måske stammer misforståelsen fra den kendsgerning, at en given hingst kan præge avlen mere end en given hoppe kan, fordi den kan nå at få flere afkom i sit liv.

Heldigvis findes der stadig avlere, som er klar over vigtigheden af at bevare og videreføre de gode hoppestammer.

Mindskes genpuljen?

Hvis jeg selv skulle have nogle skrupler over for, om man skal klone en hingst, skulle det være, at intensiv benyttelse af nogle få hingste kan være med til at mindske genpuljen. Dette forhold gælder dog allerede når der anvendes inseminering, idet hingstene også her kan få mange flere afkom, end hvis de personligt skulle bedække hver enkelt hoppe i sæsonen.

Dersom man skulle lovgive omkring dette, burde det det således også gælde ved inseminering. Eller måske skulle man sætte en øvre grænse for, hvor mange afkom en enkelt hingst får tilladelse til at blive far til. Hvis en særligt fremragende hingst når denne øvre grænse, kunne man vurdere, om dens afkom var af så høj kvalitet - herunder fri for arvelige sygdomme og andre skavanker - at der var en vægtig grund til at give yderligere bedækningstilladelse. Altså en form for klippekort, hvor fortsat kåring eller afkåring skulle tages op med mellemrum. Den første vurderingsperiode må nødvendigvis blive af mange års varighed, idet kvaliteten af afkommet, og ikke mindst deres holdbarhed i ridning, skal kunne vurderes.
Hvis man vedtog noget, der minder om ovenstånde, skulle hingste af samme klon naturligvis regnes som én hingst, og altså vurderes med hensyn til, om det var passende at den satte flere afkom i verden, frem for at lade andre hingste komme til.

\section{Har vi lov at lege Gud?}

工 ige fra den dag, hvor mennesket første gang tog et dyr til sig, og lod det leve og formere sig under menneskets indflydelse og beskyttelse, har vi ændret arvemassen. I de første mange år vidste vi bare ikke, at der var noget, der hed gener og DNA. I mange mange generationer har vi udvalgt f.eks. anderledes farver, som ville være gået til grunde i naturen, og avlet på dem fordi vi fandt dem smukke eller interessante. Uden at vide det har vi derved blandet os i naturens gang, og bestemt hvilke gener, som skulle videreføres.

Alle mennesker, som avler dyr, er moralsk forpligtet til at sikre dyrenes sundhed og velfærd, på samme måde som naturen har gjort det ved at lade dyr med uhensigtsmæssige egenskaber bukke under. Hvilke metoder vi benytter i teknologiens tidsalder har mindre betydning, end hvilke gener vi vælger skal videreføres. Når generne først er til stede i cellekernerne i et givet dyr, spiller det jo ingen rolle, hvorledes de er kommet der. De kan under alle omstændigheder videregives til afkommet, på godt og ondt. Det er i forbindelse med at skelne godt fra ondt, og hermed sikre sunde, omgængelige, holdbare - og helst også glade - heste, vores ansvar som mennesker og hesteavlere ligger.

Fotos: Knud Bonke. Hoppen hedder Sif, follet hedder Trigger og tilhorer forfatteren. Der er ikke tale om kloning. 